\title{
Erratum to: High-density mapping of a resistance gene to Ug99 from the Iranian landrace PI 626573
}

\author{
Jason D. Zurn • Maria Newcomb $\cdot$ Matthew N. Rouse $\cdot$ Yue Jin $\cdot$ Shiaoman Chao \\ Jinita Sthapit · Deven R. See $\cdot$ Ruth Wanyera $\cdot$ Peter Njau $\cdot$ J. Michael Bonman \\ Robert Brueggeman $\cdot$ Maricelis Acevedo
}

Published online: 4 April 2015

(C) Springer Science+Business Media Dordrecht 2015

\section{Erratum to: Mol Breeding (2014) 34:871-881 DOI 10.1007/s11032-014-0081-8}

In the original article, the electronic supplementary material (ESM) was published incorrectly. The correct version of ESM is provided in the below link.

The online version of the original article can be found under doi:10.1007/s11032-014-0081-8.

Electronic supplementary material The online version of this article (doi:10.1007/s11032-015-0303-8) contains supplementary material, which is available to authorized users.

J. D. Zurn · R. Brueggeman · M. Acevedo ( ()

Department of Plant Pathology, North Dakota State University, Fargo, ND 58108, USA

e-mail: Maricelis.Acevedo@ndsu.edu

M. Newcomb - M. N. Rouse - Y. Jin USDA-ARS, Cereal Disease Laboratory, St. Paul, MN 55108, USA

S. Chao

USDA-ARS, Cereal Crops Research Unit, Fargo,

ND 58102, USA

J. Sthapit

Department of Plant Pathology, Washington State

University, Pullman, WA 99164, USA
D. R. See

USDA-ARS, Wheat Genetics, Quality, Physiology and Disease Research Unit, Pullman, WA 99164, USA

R. Wanyera · P. Njau

Kenya Agricultural Research Institute, Njoro, Kenya

J. M. Bonman

USDA-ARS, Small Grains and Potato Germplasm Research Unit, Aberdeen, ID 83210, USA 